\title{
Reduction of material consumption for garments from checked fabrics
}

DOI: $10.35530 / 1 T .071 .03 .1667$

\section{ABSTRACT - REZUMAT}

\section{Reduction of material consumption for garments from checked fabrics}

The use of CAD/CAM systems have greatly optimized material utilization of garment styles from plain fabrics. Processing of intricate pattern materials is still work and material consuming. Increased material consumption is obtained because of two reasons: necessity to match pattern on ready garments and unfixed textile material structure. The fabric loss related to the pattern matching necessity is the most difficult to reduce. A style of classical women jacket was tested to compare efficiency of plain and checked fabric markers for sizes 36-54. It was determined that marker length is dependent on the conformity of the size of the checked fabric repeat and the length of the longest components placed in a sectioned marker. Reducing the length of the style slightly it was possible to reduce marker length considerably for certain size markers. Marker length, fabric consumption and, with it, product costs can be reduced conforming the length of the style to the size of the checked fabric repeat. Length tolerance - acceptable slight variations of the length of the style which does not change design and visual perception of the style should be determined by designers. Specialized software could be developed to vary the length of the style in the interval of length tolerance to reduce fabric consumption and with it product costs of certain production orders. Improving manufacturing efficiency and reducing fabric use, the styles from checked materials could be included in garment collections more often.

Keywords: checked fabrics, pattern matching, marker length, cutting room management systems, automated cutting

\section{Reducerea consumului de material pentru îmbrăcămintea realizată din țesături în carouri}

Sistemele CAD/CAM au optimizat foarte mult utilizarea materialelor pentru producția de îmbrăcăminte. Totuși, utilizarea țesăturilor cu modele complexe conduce la consum mare de material. Consumul crescut de materiale este obținut din două motive: necesitatea de a potrivi modelul țesăturii și structura flexibilă a materialului textil. Pierderea de material cauzată de necesitatea de potrivire a modelului țesăturii este cel mai dificil de redus. S-a selectat un sacou clasic pentru femei, pentru a compara eficiența încadrărilor țesăturilor simple și a celor în carouri pentru mărimile 36-54. S-a observant că lungimea încadrării depinde de dimenisunea constantă a carourilor și de lungimea reperelor dintr-o încadrare secționată. Reducând lungimea produsului a fost posibilă reducerea considerabilă a lungimii încadrării pentru anumite mărimi. Lungimea încadrării, consumul de material și, odată cu aceasta, costurile produselor pot fi reduse în funcție de lungimea produsului și dimensiunea carourilor. Toleranța la lungime - variații acceptabile ale lungimii produsului care nu schimbă designul și percepția vizuală ar trebui să fie indicate de designeri. Un software specializat ar putea fi dezvoltat pentru a varia lungimea produsului în intervalul de toleranță, pentru a reduce consumul de material și, odată cu acesta, costurile produsului pentru anumite comenzi de producție. Îmbunătățind eficiența producției și reducând utilizarea materialelor, țesăturile în carouri ar putea fi incluse mai des în colecțiile de îmbrăcăminte.

Cuvinte-cheie: țesături în carouri, potrivirea modelului, lungimea încadrării, sisteme de management a secției de croire, croire automată

\section{INTRODUCTION}

Fast fashion is changing traditional rules of fashion market and customers are demanding quick changes of wide diversity of styles produced in smaller quantities [1]. The use of different patterning of the material is one option to follow customers' demands. The same jacket can look visually very different produced from plain material, striped or checked material [2]. Garment industry should use more materials with intricate patterns to increase diversity of garment collections. To ensure it, material utilization of styles from intricate pattern fabrics should be improved with it reducing fabric and final product costs.

In garment manufacturing it is well known fact that design of garment styles are always more or less dependent on several factors which influence product costs: efficiency of production process and material costs - fabric consumption and its price. As fabric costs in garment manufacturing account more than half $(50-70 \%)$ of the total product costs, designers have to create styles which are efficient in materials use. Because of this reason not often in garment collections are included styles with increase material consumption, such as, wide and long skirts (sun cut skirts), obliquely cut skirts/dresses (figure 1) also different styles from striped or checked materials.

The use of CAD/CAM systems in garment industry has greatly optimized material utilization of plain fabrics. The industry is using different management software which organize and plan all work processes starting from style designing till sell of ready goods. During the last two decades it is supplemented with new parts [1]. Specialized software which can screen 


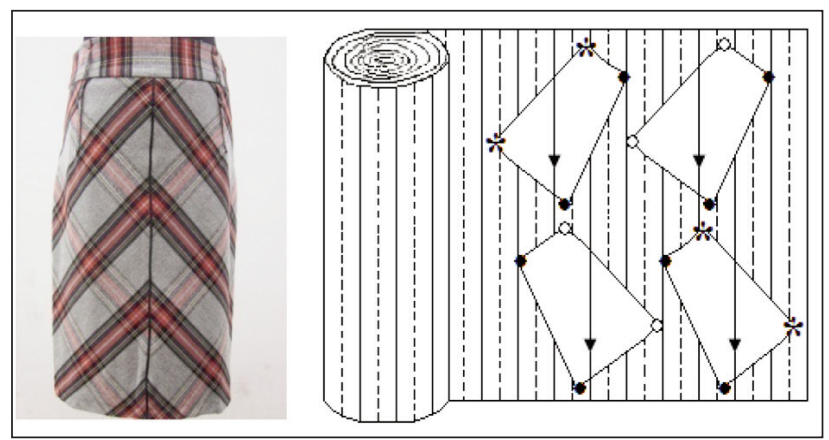

Fig. 1. Skirt with increased fabric consumption because of necessity to match fabric pattern

different nesting variants for the same order in a minute and choose the one with the highest fabric utilization level are used to reduce total fabric consumption of the order and with it also product costs [3-4]. Cut planning and scheduling improvements [5-9], as well as, possibilities to reduce fabric loss [10-11] are described in several latest papers. However, the innovations mostly improve plain fabric processing. Nesting and cutting problems of styles from intricate pattern materials are rarely researched and discussed in published sources. 1st and 2 nd edition of "Industrial cutting of textile materials" [12-13] are the only books describing manual, semi and fully automated cutting methods for intricate pattern fabrics.

\section{THE REASONS OF INCREASED FABRIC CONSUMPTION}

Processing garment styles from checked fabrics, increased material consumption comparing with plain materials is obtained because of two reasons: necessity to match pattern in all produced garments and unfixed textile material structure. Problems arising from movable fabric structure can be solved in more or less effective way depending on cutting method used: manual, semi or fully automated [14-15]. The most advanced technologies offer continues singleply automated cutting when shapes of the pattern pieces in the markers are changed in accordance with imperfect fabric structure (and with it imperfect pattern) advanced on the cutting surface (Mosaic by Lectra, AutoMatch by Gerber, Multi-array scanner (MAS) system by Bullmer, VisionCut by Gemini and Match++ by Optitex, VisionPRO by Eastman) [15]. Using the fully automated single-ply processing method, material cutting process becomes fully independent on distortions of the fabric structure/pattern during cutting process.

The fabric loss related to the pattern matching necessity is the most problematical and the most difficult to reduce. In creating markers for styles from checked fabrics, pattern pieces are placed directly on the fabric (using manual cutting) or on the image of the fabric pattern. Matched fabric pattern in the ready garment has to be obtained in both directions (vertical and horizontal) and fabric pattern has to be symmetrical in all symmetrical components. To fulfill these conditions some areas of the fabric often are left unused. Besides, to ensure the same coordinated pattern in all garments produced, the start of the marker always must be at the same position of the repeat of the fabric pattern. Very often because of this last demand the certain part of the material in all its widths has to be cut off and wasted (figure 2). In critical situation this amount of fabric can be very close to full size of one pattern repeat (figure 3). The larger is the repeat, the larger can be fabric loss [16-17].

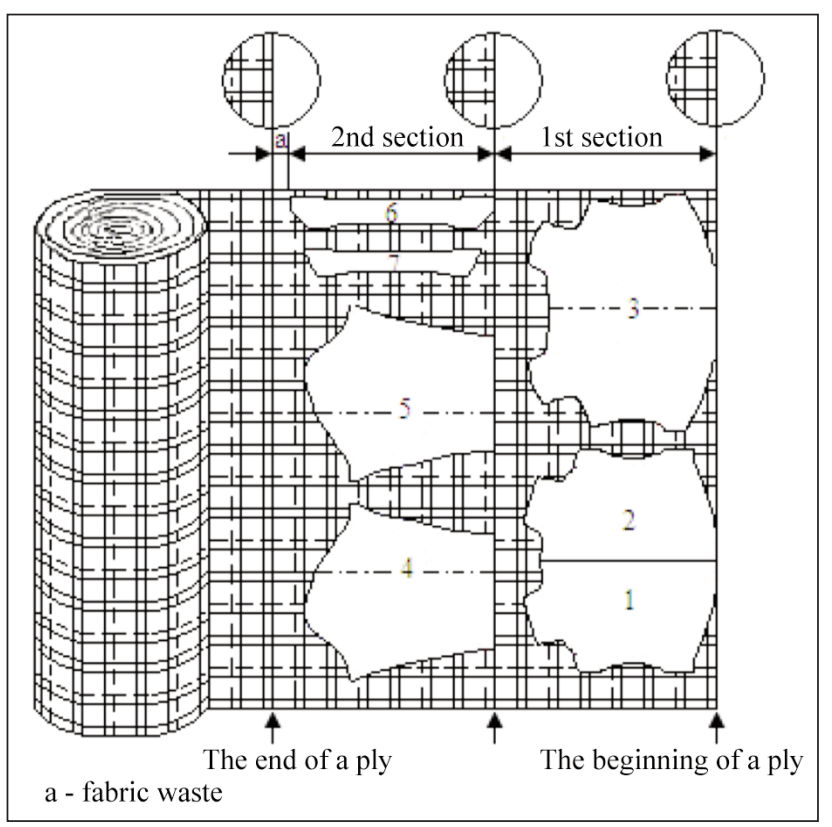

Fig. 2. Extension of marker length to match the pattern in between all garments produced

\section{FIRST EXPERIMENT}

The experiment was performed to estimate the factors that affect fabric utilization matching fabric pattern of styles from checked fabrics. 5 styles of classical women jacket were chosen. Although the styles had similar design, they differed in: length, a body part division principles (configuration and size of a front and a back side parts), a collar, pockets. Markers were created by software Mosaic (Lectra) for 10 their sizes: $36-54$ on both - plain and checked material. Total amount of tested markers - 100 (50 for plain fabric and 50 for checked fabric).

\section{Fabrics used in the experiment}

The plain and checked fabric with the same width $152 \mathrm{~cm}$ was chosen (a marker width $148 \mathrm{~cm}$ ). The checked fabric had symmetrical checks with a repeat $5.5 \times 5.5 \mathrm{~cm}^{2}$ (figure $3, b$ ).

\section{Marker making}

In making markers manually or in semi-automated way from both plain and checked fabrics, the pattern pieces of a jacket are traditionally grouped in sections to ease further cutting process (for plain and checked fabrics) and to ensure coordination of pattern on the cut components (for checked materials) [18]. Only advanced fully automated single-ply cutting 


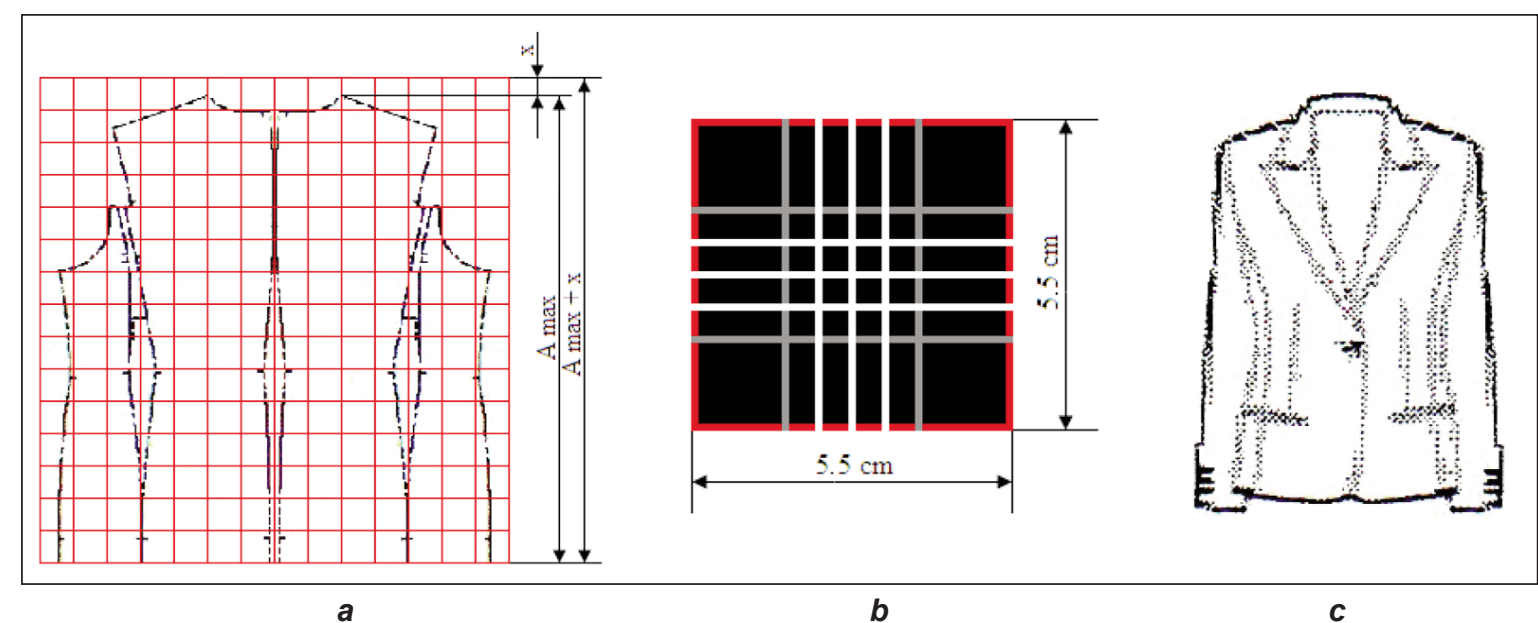

Fig. 3. The length of one section extended to the full number of fabric repeats:

$a-x$ fabric loss, $b$ - fabric repeat; $c$ - style of jacket used in the 1 st and the 2 nd experiment

method can use more efficient conventional markers where pattern pieces are not grouped in separate sections [15]. However, till now single-ply cutting [19-20] in mass production of garments is used rarely. It is fully new processing method which has to be supported with automated single-low ply cutters which are not yet typical for garment manufacturers. Because of dominate used of sectioned markers producing jackets, it was decided to use them also for experiment.

\section{Markers on plain fabric}

Pattern pieces of all sizes were laid in separate groups to create two sections:

- The first section - placed body components of the jacket: backs, back sides, front and front sides.

- The second section - placed upper sleeves, under sleeves and facings.

All other smaller size pattern pieces were placed in available free areas in the first or second section. If all body components could not be placed in the first section, one or two pattern pieces of the side components were moved to the second section (mostly for sizes up to 46, figure $4, a$ and 5,a). Analyzing obtained markers for the plain fabric, it was found that marker length was dependent on the shape and size of the components and their mutual placement in the marker. Average marker efficiency for all 10 tested sizes of 5 styles was $73.9 \%$.

Plain fabric marker length and marker efficiency for all 10 tested sizes of the style 3 (figure 3,c) are showed in the table 1. The same style will be tested also in the 2nd experiment.

\section{Markers on checked fabric}

To ensure precise pattern coordination in all cut components two different actions had to be performed by making sectioned markers on checked material:

- pattern pieces had to be placed on the fabric in certain way to coordinate horizontal and vertical lines of the fabric on the cut components and to ensure symmetry of the pattern on symmetrical components;

- certain fabric allowances had to be added around pattern pieces to support further manual or semiautomated cutting of components [14, 17-18].

\begin{tabular}{|c|c|c|c|c|c|c|c|}
\hline \multicolumn{7}{|c|}{ PLAIN FABRIC MARKER LENGTH AND MARKER EFFICIENCY } \\
\hline \multirow{2}{*}{ Size } & Marker length (cm) & \multicolumn{2}{c|}{ Marker length difference } & \multicolumn{2}{c|}{ Marker efficiency (\%) } & Marker efficiency \\
& Plain & Checked & $\mathbf{c m}$ & $\%$ & Plain & Checked & difference (\%) \\
\cline { 2 - 7 } & 152 & 165 & 13 & 7.8 & 74.3 & 69.8 & 6.0 \\
\hline 36 & 157 & 170.5 & 13.5 & 7.9 & 74.8 & 69.9 & 6.5 \\
\hline 38 & 167.2 & 181.5 & 14.3 & 7.8 & 75.3 & 69.3 & 7.9 \\
\hline 40 & 171.2 & 187 & $15, .8$ & 8.4 & 74.4 & 68.2 & 8.3 \\
\hline 42 & 182 & 198 & 16 & 8.0 & 74.6 & 66.1 & 8.5 \\
\hline 44 & 185.2 & 203.5 & 18.3 & 9.0 & 74.3 & 65.3 & 12.1 \\
\hline 46 & 195.2 & 214.4 & 19.2 & 8.9 & 74.8 & 65.6 & 12.2 \\
\hline 48 & 203.9 & 225.7 & 21.8 & 9.6 & 74.6 & 66.3 & 11.1 \\
\hline 50 & 209.4 & 232.1 & 22.7 & 9.7 & 74.1 & 66.0 & 10.9 \\
\hline 52 & \multirow{2}{*}{212.2} & 236.5 & 24.3 & 10.3 & 74.0 & 66.8 & 9.7 \\
\hline \multirow{2}{*}{54} & & & 0 & 8.7 & 74.5 & 67.3 & 9.6 \\
\hline
\end{tabular}


The largest, most important pattern pieces - both back components and both front components - were placed in the marker next to each other to ensure symmetrical placement of vertical lines in their pattern (figure $3, a, 4, b$ and $5, b$ ). All other body pattern pieces (back sides, front sides) were placed next to their main components or in some other free spaces in the markers aligning their pattern in horizontal and vertical directions. The described actions did not change the placement of the pattern pieces as similar placement of body pieces were used also in plain fabric markers.

Fabric allowances were added on side edges of symmetrical front and back components placed with their inner edges together. For other components, the fabric allowances were added on one of their sides. A fabric allowance, one repeat wide, was added also to the small components (flaps of pockets, welts, others) to coordinate their pattern later with the checks of their main components. The described actions influenced placement of the pattern pieces in width of the fabric:

- the number of pattern pieces placed in one section reduced or it was necessary to replace some pattern pieces with smaller ones in the section for the most part of tested markers (figure $5, b$ );

- comparatively large areas of the fabric appeared which had to be left unused (figure $3, b$ and $4, b$ ).

The length of minimum one section of the marker was determined by the projectional length of longest components placed in the sections - a back, a front or a facing (figure $3, a$ ). The length of the sections was also depended on a repeat of the fabric. To ensure coordinated pattern in all garments cut from more than one fabric ply, the length of the marker had to be extended to full length of " $n$ " fabric repeats (checks) (figure 2). This additional action increased the length of the markers, and with it, reduced fabric utilization.

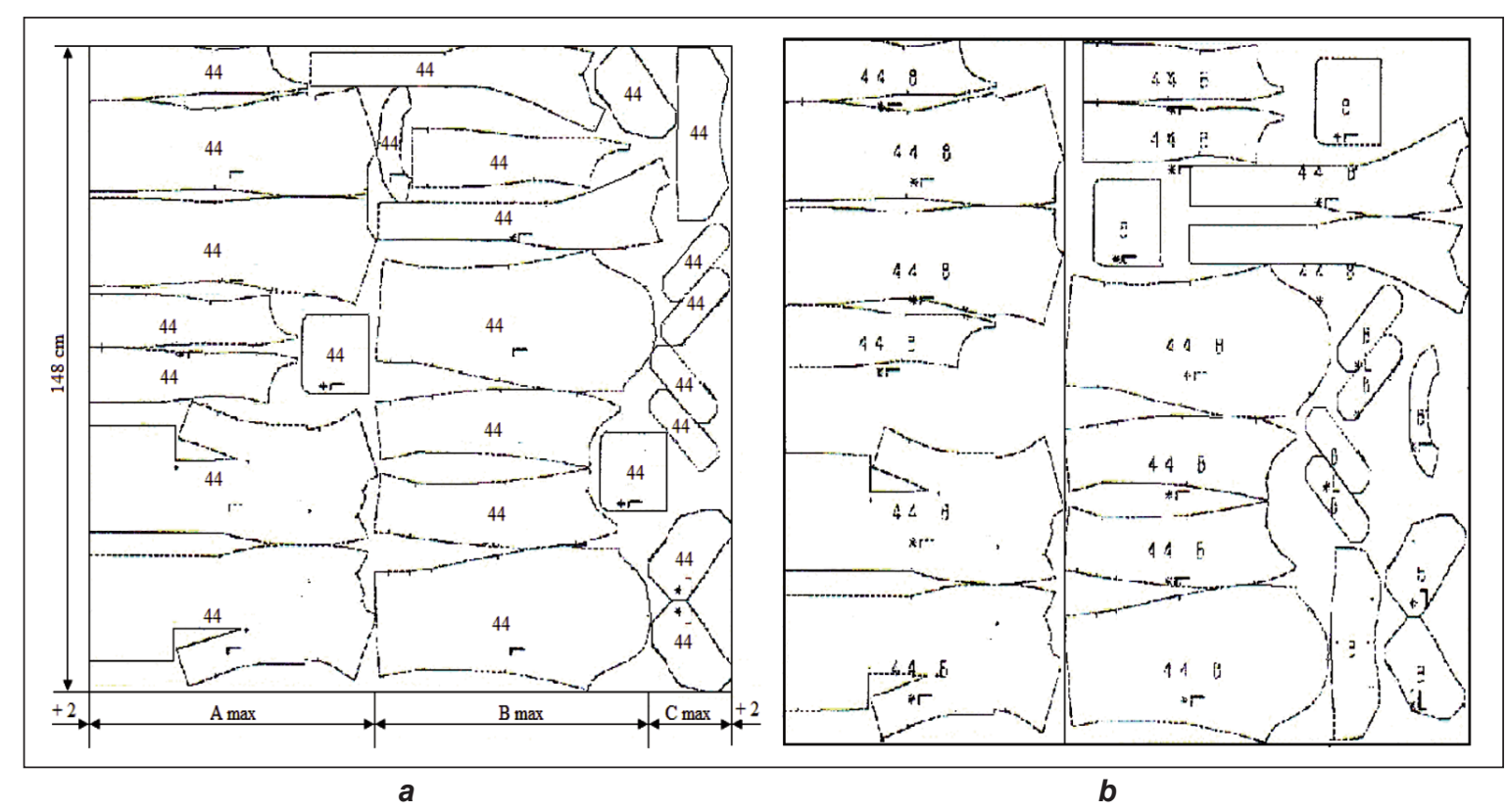

Fig. 4. Markers of the size 44 for: $a$ - plain fabric; $b$ - checked fabric

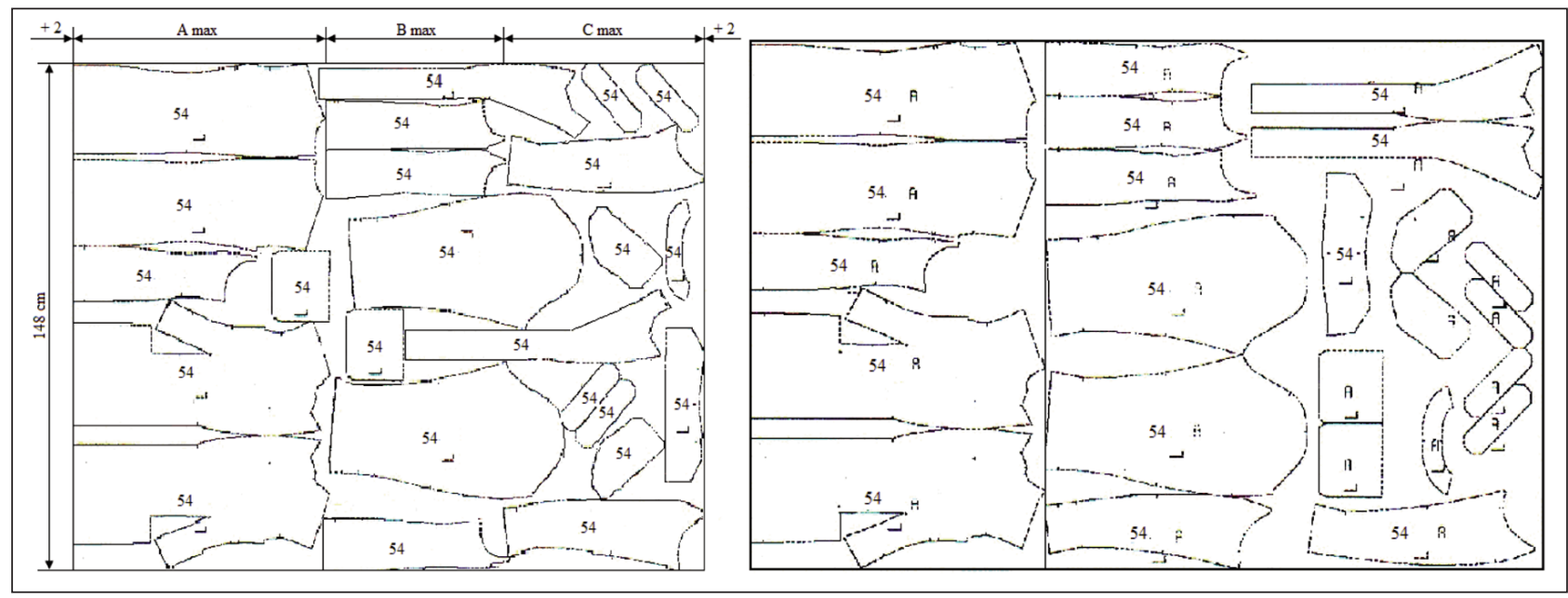

b

Fig. 5. Markers of the size 54 for: $a$ - plain fabric; $b$ - checked fabric 


\begin{tabular}{|c|c|c|c|c|c|c|c|}
\hline \multicolumn{8}{|c|}{ CHECKED FABRIC MARKER LENGTH AND MARKER EFFICIENCY } \\
\hline \multirow{3}{*}{ Size } & \multicolumn{2}{|c|}{ Original length jacket } & \multicolumn{2}{c|}{ Reduced length jacket } & Reduction of & \multicolumn{2}{|c|}{ Marker efficiency (\%) } \\
\cline { 2 - 8 } & $\begin{array}{c}\text { Marker } \\
\text { length (cm) }\end{array}$ & $\begin{array}{c}\text { Full fabric } \\
\text { repeats }\end{array}$ & $\begin{array}{c}\text { Marker } \\
\text { length (cm) }\end{array}$ & $\begin{array}{c}\text { Full fabric } \\
\text { repeats }\end{array}$ & $\begin{array}{c}\text { length } \\
\text { (cm) }\end{array}$ & $\begin{array}{c}\text { Original } \\
\text { length jacket }\end{array}$ & $\begin{array}{c}\text { Reduced } \\
\text { length jacket }\end{array}$ \\
\hline 36 & 165 & 30 & 165 & 30 & 0 & 69.8 & 68.9 \\
\hline 38 & 170.5 & 31 & 165 & 30 & -5.5 & 66.1 & 69.3 \\
\hline 40 & 181.5 & 33 & 181.5 & 33 & 0 & 68.6 & 66.8 \\
\hline 42 & 187 & 34 & 187 & 34 & 0 & 68.5 & 64.3 \\
\hline 44 & 198 & 36 & 192.5 & 35 & -5.5 & 66.1 & 68.4 \\
\hline 46 & 203.5 & 37 & 203.5 & 37 & 0 & 66.3 & 65.2 \\
\hline 48 & 214.4 & 39 & 214.4 & 39 & 0 & 65.8 & 65.3 \\
\hline
\end{tabular}

Necessity to coordinate checked pattern and the use of additional fabric allowances changed the placement of pattern pieces in the checked fabric markers and, comparing with plain fabric markers, increased their length. The marker length for checked material of all 5 tested styles increased in average for $8.2 \%$. The marker efficiency for checked material of all 5 tested styles reduced in average for $10.2 \%$.

Checked fabric marker length and marker efficiency for all 10 tested sizes of the style 3 (figure $3, c$ ), (this style will be tested also in the 2nd experiment, see below) are showed in the table 1 .

The results of the 1st experiment showed that the length of a sectioned marker (material use) is more influenced by the length of the longest pattern pieces determining the length of separate sections and the size of a fabric repeat and less influenced by mutual placement of the pattern pieces in the markers. It was also seen that there is no certain correlation between the size of the style/ pattern pieces and marker efficiency (fabric utilization). The number of other parameters and their mutual combinations (mutual placement of pattern pieces in the marker) influences marker efficiency and fabric utilization level. They are:

1. for plain fabric - the width of the fabric and the dimensions, shape, number of the pattern pieces;

2. for checked fabric - the width of the fabric, size of the repeat, kind of the repeat/ pattern (symmetrical, asymmetrical), the dimensions, shape, number of the pattern pieces and pattern matching requests.

\section{SECOND EXPERIMENT}

Performing the 1st experiment it was noticed that in few markers created for checked fabric (12 markers from 50 ) the length of a section (with it also the length the marker) had to be extended almost for whole size of the checked fabric repeat as the longest component exceeded previous repeat of the fabric for very small value - only $1-2 \mathrm{~cm}$. For example, for the size 44 of the styles 3 (figure $3, c$ ): the length of first section (determined by the length of the front/back) had to be extended from $78.6 \mathrm{~cm}$ to $82.5 \mathrm{~cm}$ - to get full 15 repeats of the fabric. Thus, the marker length extended for $3.9 \mathrm{~cm}$. To coordinate pattern in between fabrics plies this amount of fabric will be cut off and wasted (figure $3, a$ ). Producing this size jacket in large qualities fabric loss could be serious.

To try to avoid above described critical fabric loss it was decided to make the 2nd experiment. It was decided to change slightly the length of the longest components and with it - the length of the style, and to improve fabric utilization. The jacket of the style 3 which had the critical fabric loss in the 1st experiment was chosen for the 2 nd experiment (figure 3,c). The original length of the jacket $(2 \mathrm{~cm}$ above hip level) allowed to make needed changes not influencing visual perception and design of the style.

The length of the jacket was reduced for $1.6 \mathrm{~cm}$. The needed changes were performed for all components of all tested sizes and new sectional markers were created. It was seen that reducing the length of the jacket for $1.6 \mathrm{~cm}$ :

- for sizes 38 and 44 the marker length reduced (for 5.5.cm - one fabric repeat) and marker efficiency increased (size 38 from $66.1 \%$ to $69.3 \%$, for size 44 from $66.1 \%$ to $68.4 \%$ ).

- for all other sizes marker the length of the markers did not change, but the marker efficiency reduced (table 2).

The results of the 2 nd experiment show that it is possible to reduce sectioned marker length and with it fabric use reducing slightly the length of the style. Although for the 5 markers from 7 tested the length did not change but fabric utilization reduced, final positive effect - reduction of total fabric consumption - could be obtained developing certain production orders. The orders for garment sizes from "critical loss markers" are larger, the larger fabric savings can be obtained from slight reduction of the length of the style, the lower product costs for the ready goods.

\section{DISCUSSIONS}

The experiments proved that it is possible reduce total fabric consumption of certain manufacturing orders reducing fabric loss which appears because of necessity to match fabric pattern on ready garments. Marker length, with it fabric consumption, can be reduced conforming the length of the style with the 
fabric pattern repeat. Obviously the larger is the fabric repeat the larger fabric loss can appear and, and the same time, less possibilities exist to reduce fabric consumption correcting the length of the style.

Length tolerance - acceptable slight variations of the length of the style. It could be used for styles whose design and visual perception cannot be changed reducing their length in the interval of the length tolerance. The length tolerance has to be determined by the designer for the every certain style. The length tolerance could be used for different kind of garments - skirts, dresses, jackets, coats. It can be larger for longer styles and smaller or even unacceptable for short styles where length of the style is strictly determined by its proportions or completation with other styles.

Reduction of fabric consumption and with it total product costs by help of slight variations of the length of the style can be effective using semi-automated cutting methods and marker making software for patterned fabrics, such as, Mosaic by Lectra, Visual Nest by Morgan Tecnica, Match It by Bullmer, In Vision by Gerber, supplementing them with new parts [14-15]. Specialized cut planning software which screens different nesting variants for the same order and choose the one with the highest fabric utilization level is already developed and used by industry for plain fabrics [3, 4]. Similar principle could be used developing new software to detect "critical loss markers" and their importance in certain production orders (depending on ordered quantities) for checked fabric styles. Work steps could be following:

- the user of the software inserts the length tolerance for the certain style - value (in $\mathrm{cm} / \mathrm{mm}$ ) by which the length of the style could be reduced to reduce total fabric composition of the order.

- in semi or fully automated way markers are created for all necessary sizes of the order;

- software detects critical marker/markers - markers where the longest component in the section exceeds the end of the fabric report only up to length tolerance;

- software calculates how large could be total fabric loss for whole order because of the "critical markers" taking into account number of garments ordered from the "critical markers";
- software calculates total fabric consumption and compares it with fabric loss obtained from "critical markers";

- software changes the length of the components of the style for necessary value $(\mathrm{cm} / \mathrm{mm})$ to improve efficiency of the "critical markers";

- software creates new markers for all sizes of the order;

- software calculates total fabric consumption for the order and compares it with the original variant.

Above described work principle is only general. After necessary software is developed it has to be checked with new experiments and improved in detailed way.

\section{CONCLUSIONS}

In this paper the marker making of garment styles from checked fabrics was analyzed to reduce the fabric consumption for certain production orders from checked materials. The main reasons of increased fabric losses comparing with plain fabrics were determined. It was tried to find possibilities to reduce fabric consumption conforming the length of a style to efficient fabric use in sectioned markers. As the result of two performed experiments following conclusions were made:

1. The length of the sectioned marker is dependent on the shape and dimensions of the components, size of the fabric pattern repeat and the length of the longest components - the length of the style included in the marker.

2. Marker length, fabric consumption and, with it, product costs can be reduced conforming the length of the style with the size of the checked fabric repeat.

3. Designing styles from checked fabrics should be determined length tolerance - the interval in which the length of the style can be reduced not affecting its design and visual perception.

4. Using appropriate software the length tolerance could be used to reduce fabric consumption for certain manufacturing orders in efficient way.

5. Improving manufacturing efficiency and reducing fabric use, the styles from checked materials could be included in garment collections more often. They could help to raise diversity of garment collections demanded by market in efficient way.

\section{REFERENCES}

[1] Senanayake, M., Product development, production planning and selection of materials, In: Nayak, R. Padhye, Automation in Garment Manufacturing, Woodhead Publishing, Elsevier, ISBN 9780081012116, Cambridge, 2015, 19-56

[2] Beikule, I., Vilumsone, A., Vilumsone, I., Design of clothing using visual correction, In: 4th International Textile, Clothing and Design Conference - Magic World of Textiles. Dubrovnic, Croatia, 2008, 160-173

[3] Vilumsone-Nemes, I., Automated cutting room management systems to reduce fabric consumption, In: 5th International Scientific-Professional Symposium Textile Science and Economy, Tehnički fakultet »Mihajlo Pupin«, Zrenjanin, 2014, 119- 126

[4] Vilumsone-Nemes, I., Lay planning and marker making in textile cutting operations, In: Industrial cutting of textile materials, 2nd edition, Woodhead Publishing, Elsevier, ISBN-9780857091345, Cambridge, 2018, 13-26

[5] Wong, W.K., Chan, C.K., IP, W.H., Optimization of spreading and cutting sequencing model in garment manufacturing, In: Computer Industry, 2000, 43, 1, 1-10 
[6] Wong, W.K., Chan, C.K., An Artificial Intelligence Method for Planning the Clothing Manufacturing Process, In: Journal of Textile Institute, 2001, 92, 2, 168-178

[7] Kwong, C.K, IP, W.H., Chan, C.K., Wong, W.K., Optimization of manual fabric cutting process in apparel manufacturing using genetic algorithms, In: International Journal of Advanced Manufacturing Technology, 2005, $27,1,152-158$

[8] Wong, W.K., Guo, Z.X., Leung, S.Y.S., Applications of artificial intelligence in the apparel industry: a review, In: Textile Research Journal, 2011, 81, 1871-1892

[9] Wong, W.K., Guo, Z.X., Leung, S.Y.S., Optimizing decision making in the apparel supply chain using artificial intelligence (Al): From production to retail, Woodhead Publishing, ISBN 9780857097798, Cambridge, 2013

[10] Dumishllari, E., Guxho, G., Influencce of lay plan solution in fabric efficiency and consume in cutting section, In: AUTEX Research Journal, 2016, 16, 4, 222-227

[11] Azmat, H., Naveed, T., Zhong, Y., Reducing fabric wastage through image projected virtual marker (IPVM), In: Textile Research Journal, 2017, 88, 14

[12] Vilumsone-Nemes, I., Industrial cutting of textile materials, 1st edition, Woodhead Publishing, Elsevier, Cambridge, 2012

[13] Vilumsone-Nemes, I., Industrial cutting of textile materials, 2nd edition, Woodhead Publishing, Elsevier, Cambridge, 2018

[14] Vilumsone-Nemes, I., Multiply processing of styles from intricate pattern fabrics, In: Industrial cutting of textile materials, 2nd edition, Woodhead Publishing, Elsevier, Cambridge, 2018, 241-253

[15] Vilumsone-Nemes, I., Automated single ply processing of styles from intricate pattern fabrics, In: Industrial cutting of textile materials, 2nd edition, Woodhead Publishing, Elsevier, Cambridge, 2018, 255-265

[16] Vilumsone-Nemes, I., Marker making for garment styles from intricate pattern fabrics, In: Industrial cutting of textile materials, 2nd edition, Woodhead Publishing, Elsevier, Cambridge, 2018, 255-265

[17] Vilumsone, I., Spulgite, M., Purina, B., Beikule, I., Marker making for materials with striped patterns, In: Scientific Proceedings of Riga Technical University, 9th part: Material Science Textile and Clothing Technology., Riga, Latvia, 2009, 4, 119-125

[18] Vilumsone-Nemes, I., Manual marker making, spreading and cutting materials with check patterns, In: Industrial cutting of textile materials, 1st edition, Woodhead Publishing, Elsevier, Cambridge, 2012, 171-179

[19] Nemeša, I., Automated knife cutting systems to process textiles, In: Tekstilna Industrija, 2017, 4

[20] Nemeša, I., Automatizovano jednoslojno krojenje tekstilnih materijala, In: Tekstilna Industrija, 2018, 2, 23-29

\section{Authors:}

\section{INETA VILUMSONE-NEMES ${ }^{1}$, DANA BELAKOVA ${ }^{2}$}

${ }^{1}$ University of Novi Sad, Technical faculty "Mihajlo Pupin”, Department of Textile Sciences and Clothing Design Đure Đakovića bb, 23000, Zrenjanin, Serbia

${ }^{2}$ Riga Technical University, Institute of Design Technologies of the Faculty of Materials Science and Applied Chemistry, Kīpsalas 6, Riga, Latvia

e-mail: dana.belakova@rtu.lv

Corresponding author:

INETA VILUMSONE-NEMES

e-mail: inetavil@gmail.com 